\title{
Research on the Reform of Accounting Talents in the Background of the Transformation of Colleges and Universities
}

\author{
Qun Wei and Xiang Zhang
}

Jingdezhen Ceramic University, Jingdezhen, Jiangxi 333403

\begin{abstract}
As colleges and universities are increasingly linked with the society, the previous "ivory tower" training mode can no longer meet the demand of social development and students' employment demand, and colleges and universities are increasingly become application-oriented, which is the inherent law of higher education and the inevitable result of colleges and universities' own choice. This paper analyzes the background of the transformation and development of colleges and universities, points out the problems existing in the cultivation of accounting talents, and puts forward the strategy of constructing the training mode of applied accounting talents.
\end{abstract}

Keywords: Transformation of Colleges and Universities; Accounting, Talent training; Reform

\section{高校转型发展背景下的会计学专业人才培养改革}

\section{研究}

魏群, 张翔

(景德镇陶瓷大学 江西省 景德镇 333403 )

摘要: 随着高校与社会的联系日益紧密, 过去的 “象牙塔” 培养模式已经远不能满足社会的发展需要和学生的就业需求, 高校向应用型方向转型, 是高等教育内在规律和自身选择的必然结果。本文分析了高校转型发展的背景, 指出会计学应用型 人才培养存在的问题, 提出应用型会计人才培养模式构建的策略。

关键词: 高校转型 会计学 人才培养 改革

中图分类号: E232.5 文摘标识码: A

\section{1. 高校转型发展的背景}

截至 2015 年 5 月 21 日, 我国高等学校共计 2845 所, 其中: 普通高等学校 2553 所, 增长率达到了 $12 \%$ 左右。目前, 按照国际统一口径, 我国高等教育毛入学率已经达到 $26 \%$, 进入大众化阶段, 2020 年毛 入学率将达到 $40 \%$ 。教育部规划司副司长陈峰认为, 大学按照社会需求, 可分为研究型、应用技术型和其 他类型, 虽然研究型人才对国家非常重要, 但是, 社会发展需求量更多的是应用技术型人才。大学不能都 是研究型的, 经济社会发展需要一批应用技术型的大学。

欧洲许多国家在上个世纪 70 年代开始创办应用技术型大学, 至今已有 30 多年的历史。我国教育部、 发改委、财政部 2015 年印发的《关于引导部分地方普通本科高校向应用型转变的指导意见》指出为推动 转型发展, 高校把办学思路真正转到服务地方经济社会发展上来, 转到产教融合校企合作上来, 转到培养 应用型、技术技能型人才上来, 转到增强学生就业创业能力上来。我国高校的转型发展, 实质上是高等教 育供给侧结构性改革, 目的是培养本科层次的职业技术人才, 使毕业生既接受系统的理论训练, 又有一定 的技能, 实现产教融合发展。在轰轰烈烈的高校转型发展中, 会计学专业人才培养仍然存在各种问题, 如 何适应新的发展形势，破解趋同发展的难题，以获得更好发展，是我们不得不思考的问题。 


\section{2. 转型发展背景下会计学应用型人才培养的问题分析}

\section{1 培养目标问题}

大多数高校会计专业人才培养目标一般为培养应用型高级专业人才。会计专业应用型人才是未来面向 社会工作生产一线的高素质技术技能型人才, 其所需的知识、能力和素养与研究型、技能型人才不同, 然 而在部分高校的培养过程中, 教学方式与内容倾向于学术型教育, 会计学专业设置及课程体系基本沿袭传 统的学术性院校的模式, 突出宽口径、厚基础, 理论体系的系统化与完整性, 未考虑市场对人才需求的产 业特征与行业导向, 各层次高校的课程体系具有趋同性, 重点以传统的财务会计方向为主, 跨专业、跨领 域复合型、通用型的培养很少, 没有建立服务于社会的整体教育架构。由于生源素质的影响和教师实务技 能的缺失, 使得应用型高级专门人才没有实现, 学术研究型人才也没有培养成, 由此造成高校会计人才培 养与社会需求错位。而且一些高校新设专业主要依据市场是否热门, 使得会计专业设置和建设与区域社会 经济结构契合度比较低, 短期行为较明显。

\section{2 教学体系问题}

多数高校会计人才培养模式注重 “宽基础、广口径”，教学过程中偏重于基础知识的讲授和相关科学 理论的介绍, 而缺少应用能力和实践能力的培养; 课程设置和教学目标包括通识教育而缺少人文教育, 缺 乏对人文教学体系的构建。其结果造成学生只会背理论知识, 而不能灵活运用, 严重缺乏理论研究能力和 技术创新的能力, 同时也不具备会计岗位需要的实操本领, 成为知识不足, 缺失文化的一群所谓高等人 才，使得会计这么一个技能型强的专业毕业生就业受阻。

\section{3 师资队伍问题}

建设 “双师型”教师队伍是培养应用技术型人才的重要环节，也是实现转型发展的重要因素。然而多 数高校在引进会计学教师都是注重高学历, 不切实际地追求引进高层次人才, 来源渠道单一, 不注重自身 教师的企业定岗实践和学历深造, 会计学专业教师的成长经历都在学校, 缺少会计学专业的实践经验, 教 师的实训指导能力薄弱, 是清一色的理论型教师。会计学专业教师顶岗培训, 学校往往没有政策支持, 企 业又担心机密外泄等原因, 这就使得 “双师型” 教师队伍建设无法实际落实, 而真正的 “双师型” 人才, 又很难引进。

\section{4 培养方式问题}

目前, 大部分高校会计学专业教学模式仍然选择以教材、课堂和教师为中心, 灌输式教学方式为主, 开设的理论课程如公共必修课、选修课和专业基础课等比例偏大, 并且在教学方式上采用的是以讲授为主 的理论教学。虽然, 一些会计学课程已经开始加大案例教学, 微课教学等方式, 但在适应市场适应经济发 展方面还做得不够, 缺乏必要科学的实践教学材料、手段和实验实训设备以及掌握实践教学技能的教师。

我国教育部早已提倡启发式、讨论式、参与式教学, 要求教师科研与教学相结合, 结合研究项目进行 案例教学, 且产教融合、校企合作项目早已推广。但完全落实到位还存在许多问题, 缺少保障会计学专业 教师提高自身产教融合能力的政策支持, 职称评定方法不合理, 往往使得会计学专业教师潜行研究而忽视 产教融合, 传统教学方式和教学习惯在会计学专业教学过程中依然根深蒂固。

\section{3. 应用型会计人才培养模式构建的策略}

在供给侧改革的推动下, 高校办会计学专业时必须明确如何建设一个专业, 弄清楚会计专业服务的对 
象, 了解会计行业人才质量标准, 确定人才培养类型和人才培养体系, 整合师资队伍建设, 改革教育教学 模式等问题，使人才培养与社会需求相契合。

因此，高校要根据自身发展和会计专业发展状况，可以选择多元化教学体系，但总体层面上必须偏重 培养高层次技术技能型人才, 真正落实如何培养会计专业高层次技能型人才问题, 使会计毕业生能够满足 未来岗位要求和市场社会要求。

\section{1 转变会计学专业建设理念}

理念指导实践的灵魂, 高校要实现会计人才培养向应用型转变, 首先要建立合理的会计学专业建设理 念, 理清建设思路。首先, 会计学专业设置应与地方经济发展的需要、结合产业结构调整, 以市场需求为 导向的指导原则, 立足地方、开放办学, 建立行业指导、企事业单位专业人员参与专业设置评议制度。其 次, 会计学专业建设理念要有特色性。不同性质的高校为其毕业生打造了适合自身办学特色的就业渠道。 例如, 景德镇陶瓷大学的会计学专业应与陶瓷行业密切联系, 抓住办学特色, 向各类陶瓷行业输送人才, 以特色求生存, 求质量, 与产业需求相结合, 能够更好地增强学生的就业竞争力。第三, 会计学专业发展 要有预见性。根据社会发展趋势和高等教育发展的规律, 合理预见专业发展趋势, 及时调整专业建设思路, 才能引领地方经济发展, 推动社会进步。

\section{2 产教融合发展}

会计学专业是实践性很强的专业, 要实现产教融合发展, 要改变校企合作流于形式的局面, 关键要形 成 “双赢” 的合作基础, 建立 “双赢” 的合作机制, 搭建产学研平台, 扩大与地方企业的合作研究, 寻找 双方共同发展的切入点, 在合作中实现资源共享, 开展互利双赢的项目, 如学校为企业提供管理咨询, 专 业培训, 软件开发, 建立财务预警体系, 岗位助理, 顶岗实习等; 企业为学校提供会计业务实践, 会计类 课题实验, 参与财务管理、提供会计教学案例等资源环境。另外, 高校可承担新建经济开发园区基础教育 发展规划的设计任务, 承接地方经济发展的研究课题; 可依托园区人才中心为会计学专业毕业生搭建就业 平台, 依托大学生创业基地, 为大学生创新创业搭建平台, 依托特色专业优势, 对接金融商贸、财务管理 服务、财务软件开发、会计基础教育等方面的服务合作，促使经济效益与社会效益同步提高，政府、企业、 高校、会计学专业学生各方受益。

\section{3 以全面发展为指导, 建立多元化教学体系}

在全面发展教育理念下, 制定高等教育会计学专业培养目标, 要以学生为本, 以学生发展的需要为目 的, 建立多元化教学体系, 把学生培养成真正自由的、全面发展的人, 而不是要把培养成作为工具的人、 片面发展的人。在会计学专业建设上, 要结合社会需求和全面发展的需要, 充分考虑到学科间的整合和联 系, 按照 “以宽为主、宽窄兼顾” 的原则, 合理确定专业口径。在会计学专业课程设置上, 要注重相关学 科或领域知识的交叉和融合, 完善课程体系, 丰富教学内容。在教学方法上, 要激励教师在教学中根据会 计学专业特色, 采取讨论法、任务驱动教学法、自主学习法等多种教学方法, 同时实行 “三个课堂” 的人 才培养方式, 即第一课堂的课程教学、第二课堂的校园活动、第三课堂的社会实践。在成绩考评体系方面, 积极推进多元考核评价体系改革和创新, 对学生进行多方面、多角度的考核评价, 建立知识和技能、过程 与方法、情感、态度和价值观等多维评价体系, 从专业知识、学习态度、活动参与、实践技能、创新能力、 决策能力和团结协作能力等多方面进行考核评价, 促进学生的全面发展。 


\section{4 加强 “双师型” 教师队伍建设与培养}

要培养适应社会发展的学生, 教师首先要具备将学科专业知识转化为产业行为的能力。高校教师队伍 建设往往重学历、讲出生, 忽视实践应用能力的模式, 这阻碍了高校的转型发展。“双师型” 教师队伍建 设, 采用 “引进来, 走出去” 同步推进, 如从会计师 (税务师) 事务所、生产型、商贸型大中型企业聘请 专业人员，带着工作中实际业务、审计项目，以及生产企业的成本计算等案例进校讲学、讲座，使学生贴 近企业实际，促进产学研融合，增强学校与企业的合作力度，让一线教师与企业专家相互交流互动，让一 线教师也能有企业工作经验，改变教师队伍的知识和能力结构。高校应制定相关政策支持中青年教师到境 内外高校、科研机构和大型企业访学研修, 从提高会计学专业教师能力入手, 从而提高会计人才培养的质 量。

高校会计专业转型发展与教师自身素质提高有密切关系。高校还需要建立合理的人才评价机制, 以提 高教师主动性, 以评价制度指引, 带动会计学专业发展, 促进产教研学融合, 逐步引导高校会计专业发展 向应用型方向转变。

\section{致谢}

基金项目：本文系 2016 年江西省高校教改课题《基于高校转型发展的会计学专业人才培养改革研究 一以江西省高校为例》 (项目编号：JXJG-16-11-18)、《一般工科院校财会类应用型人才 “产学研” 协同 培养模式研究》（项目编号：JXJG-16-11-10）阶段性研究成果。

\section{Acknowledgement}

Fund Project: This paper is the periodical research result of 2016 Jiangxi Colleges and Universities' teaching reform topic "Research on the reform of accounting professional training based on the transformation and development of colleges and Universities -- a case study of colleges and universities in Jiangxi” (Project No.: JXJG-16-11-18) and "Research on the Cooperative Training Mode of "Production, Teaching and Research" of Accounting Talents in General Engineering Colleges" (Project No.: JXJG-16-11-10)

\section{参考文献:}

[1］张红梅. 地方高校转型发展及应用型人才培养模式探究. 河南教育(高教). 2015.2

[2] 李新丽. 地方本科院校会计学专业转型发展策略. 新乡学院学报. 2016.10

[3] 颜莉. 独立学院会计学专业培养模式调查分析. 湖北经济学院学报 (人文社会科学版). 2012.9

\section{作者简介:}

魏群 (1982. 10-), 女, 汉族, 江西南昌人, 硕士, 景德镇陶瓷大学计划财务处, 高级会计师, 研究方向: 会计学、教 学管理

张翔（1976.12-)，男，汉族，江西吉安人，硕士，景德镇陶瓷大学教务处，讲师，研究方向：教学管理

\section{References:}

[1] Zhang Hongmei. A Study on the Transformation and Development of Local Colleges and the Cultivation of Applied Talents. Henan Education (Higher Education). 2015.2

[2] Li Xinli. Reform Strategy of Accounting Specialty Transformation in Local Universities. Journal of Xinxiang University.2016.10

[3] Yan Li. Investigation and Analysis on the Training Mode of Accounting Major in Independent Colleges. Journal of Hubei University of Economics (Humanities and Social Sciences).2012.9 